\title{
Temporarily New: On Low Fertility and the Prospect of Pro-natal Policies
}

\author{
Dirk J. van de Kaa*
}

\begin{abstract}
Concern about the low levels of fertility in Europe appears to be spreading. In political circles voices advocating the design and implementation of pro-natal policies are growing louder. The traditional fear of population decline is refuelled in numerous conference papers and at meetings specifically set up to let policymakers meet demographic experts. This paper aims to contribute to the discussion by arguing that just as in the 1930s, and in the early 1970s when fertility first dropped below replacement level, expressed concerns do not necessarily lead to pro-natal policies. After a brief discussion of the raisons d'êtres of governments, and of the purposes and types of population policies, a series of propositions is presented that make it reasonable, at the very least understandable, that democratically elected governments act with great prudence in such matters. Their basic policy goals are not endangered and they are faced with other more serious priorities. Europe's past has mainly yielded lamentable examples, the position of national administrations vis-à-vis their population has changed so that fertility is largely beyond governmental control, and it is probably wrong to assume that the common difference between mean desired family size and completed family size is essentially due to the lack of support for families. It is concluded that concern about numbers may be a temporary phenomenon and that in many ways it makes more sense for governments to invest heavily in the children that are being born.
\end{abstract}

\section{Introduction}

Demographers projecting the population of their country are seldom pleased with the outcome. Given the best assumptions about future trends that can be made they see serious problems arising from growth that is either too rapid or too slow and from changes in the population structure. Demanding government action and suggesting specific policies is but one step away. Few resist that temptation. But

* Netherlands Interdisciplinary Demographic Institute (NIDI), P.O. Box 11650, NL-2502 AR, The Hague, The Netherlands. Email: DJVanDeKaa@cs.com 
while demographers may be right in their diagnosis that as a consequence of specific demographic trends serious geo-political, social and economic issues loom ahead, the response of governments tends to remain vocal and in practice is slow and half-hearted at best. I will argue that even in the present situation of lowest-low fertility in industrialised countries this political reaction is appropriate, at the very least understandable. There are very good reasons for governments to be prudent in re-allocating resources for pro-natal purposes. This partly, because they have even more pressing matters at hand and partly because it must be assumed that the demographic regime change underway since the mid-1960s has not yet come to an end. Moreover, the same forces underlying that regime change, and by implication the shift to lowest-low fertility, have changed the relationship between the government and the people. The traditional political and administrative operating system has become obsolete. Governments are no longer in a position to use an advantage in knowledge and power to formulate generic policies and solutions and to enforce these. Increasing the official age at retirement by two years, for example, requires spreading it out over several decades. In the reflexive modern, newly unordered societies experiencing the effects of the regime change frequently called the Second Demographic Transition, subtle approaches are required. Consequently, the demographers' focus on the pressing need for strong, explicit pro-natal policies will remain only temporarily 'new'.

\section{What are National Governments for?}

National governments fulfill a multitude of tasks. Commonly their existence is taken for granted. But what are the most essential raisons-d'être of national governments? They have two basic responsibilities. A national government has:

- To maintain the territorial integrity and national sovereignty of the state, and should

- Aim to improve the quality of life and wellbeing of the population it represents.

How these two basic responsibilities are translated into the main goals, or primary objectives, pursued by government departments depends on a variety of factors. They may be largely religiously inspired, may have a theoretical foundation, or may use a specific ideology as point of departure. Invariably such a set of objectives will be abstract in character and will reflect the interplay of competing societal forces. The precise nature of that set of goals is commonly ascertained by studying the objectives stated in the policy papers of different government departments and by looking at the allocation of tasks over such departments. To expect all objectives to be fully compatible is unrealistic. The 
goal of assuring a high rate of economic growth may come into conflict with the goal of protecting the environment. Similarly, the explicit objective of enlarging the opportunities of each individual to lead a meaningful life and to follow a life course of one's personal choice may easily clash with the goal of maintaining a fair social order. The objective of wanting to contribute to peace and security in the world may be interpreted differently by the departments of foreign affairs and defense. And it requires little imagination to see that there may even be instances in which maintaining the national sovereignty is disadvantageous for the longterm economic welfare of a population.

\section{What are Population Policies for?}

Population policies, however defined, can never be a goal in themselves. They are best characterised as being secondary in nature. They are not formulated simply because there is a population. No, they have to serve the realisation of the basic and primary policy objectives as discussed above.

Following Doublet (1949), Berelson $(1971 ; 1974)$ has distinguished three groups of policy measures that jointly constitute the population policy of a country. These are (i) measures that aim to exert a direct influence on demographic events such as fertility, mortality and migration, or that have a direct bearing on the size, composition, or distribution of the population; (ii) measures which although not formulated with demographic intent are cognizant of their likely demographic effects, and (iii) measures which although not taken with demographic intent have, or are assumed to have, non-negligible demographic effects.

Changes in population policy emanate from changes in demographic conditions or prospects, from changes in the social and economic circumstances of a country, from changes in national policy goals, or from a combination of these. Currently it is mainly the almost unprecedented low level of period fertility that stimulates quite a few demographers of repute to ring the alarm bell and to call upon their governments to take immediate action to increase the number of children born per woman. They demand urgent policy measures of the first type that will exert, or are supposed to exert, a direct influence on the level of fertility and, consequently, on the rate of natural population growth and the age structure. But isn't it understandable that governments are loath to take measures with direct demographic intent? 


\section{Why is Prudence Appropriate?}

One may list a variety of reasons that make it understandable why in the current setting governments of the industrialised countries of Europe and in other industrialised parts of the world are reluctant to introduce explicit pro-natal policies. These can be grouped as follows:

\section{Basic policy goals not endangered}

The continuation of lowest-low levels of fertility for any length of time will inevitably have geopolitical repercussions. This is particularly evident when population projections for European countries are contrasted with similar estimates made for selected countries elsewhere in the world (Demeny 2003). But that does not imply that the basic objective of maintaining national sovereignty and the territorial integrity of the state is endangered. To serve that goal one simply needs power. As Organsky and Organsky stated in the early 1960s when concern about the diverging population trends in the various parts of the world was equally great, it is naïve to equate power with military might and population numbers. It includes '... the power to influence the quiet course of peaceful events. Power is the ability to influence the thoughts and behaviour of others. All nations have this ability to some extent, and all are constantly exercising it in one way or another' (Organsky and Organsky 1961: 9).

The determinants of national power are manifold. Population numbers have been identified as being important in that regard (Davis 1958). For one they are the principal factor in the labour force, are highly relevant for the size of the economy of a country, also directly influence the potential size of the fighting forces, while '... consolidation of a victory in war often requires a sizeable occupation force'. But power is not merely a question of numbers.

The power of nations is also seen to be closely related to their wealth. In fact, on an earlier occasion, Davis (1954) had already concluded that the power of a country was best measured in terms of its GNP. In the course of time further elements have been added and specified, such as the skill and efficiency of the government, size of territory, geographical location, natural resources, growth rate, levels of education, civilian morale, political ideology and willingness to suffer. In the mid-1970s Cline (1975) made an attempt to study the 'politectonics' in the world, as he called it, more systematically. He developed an approach that I have not seen improved and that defines the Perceived power ( $\mathrm{Pp}$ ) of a country or region as a function of its Critical mass (C), Economic capability (E), Military capability (M), Strategic purpose (S) and Will to pursue a national strategy (W). In his formula $\mathrm{Pp}=(\mathrm{C}+\mathrm{E}+\mathrm{M}) \times(\mathrm{S}+\mathrm{W})$ population size forms part of $\mathrm{C}$ (the critical mass) but can contribute at most $10 \%$ to the total value of the $\mathrm{Pp}$ of a given state or region.

One need not fully subscribe to Cline's approach to appreciate that population size per se is not such an important determinant of power, that raising fertility to 
replacement level or above would not be a suitable way to counteract the strategic drift inherent in the diverging population trends in the various parts of the world. This even if it is assumed, that an increase in fertility and natural growth rates would also have a positive effect on other determinants of power. The individual industrialised countries in the European region affected by lowest-low fertility have little choice but to band together so as to become less vulnerable and to conclude treaties that may afford protection. This process is, in fact, well under way. Both NATO and the European Union have extended beyond belief and while in the European region the integration is experiencing setbacks the expansion is bound to continue. Turkey may well join within two decades and so may the Ukraine, the Balkan states currently out of favour, and ultimately even Russia. The paradoxical conclusion can be no other than that for states which because of their small population size will never be a major force in the world, the best way to preserve their territorial integrity may well be to transfer part of their national sovereignty to a supra-national entity.

Will the second basic goal of maintaining and enhancing the quality of life of their populations also remain possible in countries with very low fertility if it is not raised? To give a categorical answer is not possible. All one can say is that, so far, growth in GDP per capita in the OECD countries has continued. It is true that during 1990-98 that rate of growth was slightly lower than during 1980-90 (1.8 versus $2.1 \%$ ) but that reflects an economic recession rather than a demographic effect. In 2004 the GDP per capita in 30 OECD countries, based on current purchasing power, amounted to USD 27800 , an average negatively affected by the low levels still observed in some eastern European countries. Given that disposable incomes have continually risen, such economic and structural problems as exist in the OECD countries can hardly be attributed to reduced rates of natural population growth or declining population numbers. Much depends, furthermore, on the precise definition of the concept 'quality of life'. In a paper prepared for a conference on declining fertility in Europe organised by the Council of Europe in 1976 I have argued that it depends on the degree to which three groups of human needs are fulfilled: “... the primary needs, which are essentially physiological and economic, for example housing, clothing, food; the secondary needs which are essentially social, for example security, dignity, justice; and the tertiary needs which are essentially of a cultural nature, for example, the need to participate, to be creative, to achieve self-fulfillment and harmony" (Van de Kaa 1978: 226-7). Economic forecasts commonly foresee a further, sometimes even quite substantial, increase in GDP per capita. There is no doubt that if lowest-low fertility were to persist for an extended period of time and no significant recuperation due to postponement were to occur this could affect the (rising) standard of living of the populations concerned. That is to say, certain groups in these populations could see their relative standard of living decline. Not that single mothers, the aged and the chronically ill would suffer abject poverty, but it would become increasingly difficult for governments to 
raise the funds required to maintain and cover all age-related social and welfare benefits. The messages governments receive from economists in this regard are, however, not unequivocal. ${ }^{1}$ Some prefer to stress the advantages also associated with it.

Moreover, depending on the degree of foresight displayed by the different governments and on anticipatory measures already taken the magnitude of such difficulties will vary. If proper pension schemes relying partly on capital investment and partly on pay-as-you-go arrangements are in place and the governments themselves have built up a sizeable reserve they will not be serious. If governance has been poor the situation is quite different. But the magnitude of the problems will even then depend largely on how well these governments will deal with the need for structural economic and social reforms they are confronted with. Without major structural reform the economic future of most industrialised countries in the West is bleak. Then they will not be able to improve their economic performance and will not reach an annual rate of economic growth in the order of $3 \%$ that would allow the absorption of many of the consequences of ageing. This makes carrying out structural reforms a much greater priority than the issue of low fertility. Moreover, to the extent that stagnant economic growth is implicated in the decline of fertility, prioritising economic revival might well help to redress it. In countries rich in natural resources, such as Australia (ores, minerals, coal), the Netherlands (gas), and Norway (oil), which can count on deriving large incomes from the sale of these products, the situation is easier. If they are willing to channel part of that income to covering rising pension and social security costs they may be able to avoid having to increase the ratio of total tax revenue to gross domestic product (GDP). Within the 30-nation OECD area that ratio has fallen slightly, from $37.1 \%$ in 2000 to $36.3 \%$ in 2003 , but it may well be argued that the overall share of taxation in the economies of the region is still too high in the globalisation that the region faces.

The most difficult constellation of factors and the most serious societal consequences must, of course, be expected in countries affected by both very low fertility and poor governance. Would not pro-natal policies be appropriate there? Perhaps, but while the poorest and most under-privileged groups of the population in such countries may well be responsive to pro-natal policies, these countries are precisely the countries least likely to be able to afford them and also to implement them successfully, with efficacy and fairness.

\footnotetext{
It may be a national idiosyncrasy, but the main economic advisor of the Netherlands, the director of the Central Planning Office, Henk Don, recently stated in a newspaper interview that a declining population was not an 'economic problem' (NRC, 09-02-06). Several months earlier, Joop Hartog, a professor of economy at the University of Amsterdam, confessed in the same journal to breaking out in sweat when he hears colleagues advocate measures to promote births. He argues that the income per capita does not depend on the number of heads, and sees more advantages than disadvantages in having a smaller national population.
} 


\section{Structural reforms have priority over pro-natal policies}

It is generally recognised that the industrialised countries of the West, and particularly those in Europe, face a number of structural challenges. The persistence of sluggish economic growth in most OECD countries, in the European Union, and the Euro zone understandably has created a good deal of uneasiness and uncertainty about the economic prospects in the region. It has sapped consumer confidence. The diagnosis is fairly straightforward. The region is increasingly affected by developments elsewhere in the world and feels the impact of what is loosely called globalisation. According to Blossfeld and Mills (2005) that process comprises four interrelated shifts:

1. The swift internationalisation of markets after the end of the Cold War;

2. The rapid intensification of competition following deregulation, privatisation and liberalisation within industrialised countries;

3. The accelerated diffusion of knowledge and the spread of networks connecting markets around the globe;

4. The increasing impact of these markets at the national level and their dependence on events that may happen anywhere in the world.

Together these shifts have mercilessly exposed the weaknesses of the European and similar economies. Siebert (2005) who investigated ways of getting Germany's economic engine going again identified three major challenges. These are to 'undo the false incentives that are the root cause of high unemployment', 'how to reduce the tax on labour and how to make the social security systems sustainable' and, more generally, 'how to get a more dynamic economy'. These challenges are to varying degrees common to all western European countries. The welfare states of the Western world apparently are vulnerable: their labour market is too rigid and does not allow easy firing and hiring; the skills and motivation of part of the labour force do not match current demand; the system of wage negotiations is not flexible enough and too centralised; the gap between gross and net hourly wages is much too large and drives firms out; the level of taxation is too high and certainly cannot be raised any further; the number of working hours in Europe is too small when compared to the USA let alone in comparison to newly developing countries-1276 working hours in 2003 in the USA versus 934 in Germany-(Brouwer 2005); unemployment and other social benefits are too generous; not enough is invested in research, innovation and development; the integration of migrants is unsatisfactory; the black or grey economy is too large and relies almost entirely on illegal migrants, and so on. The litany of complaints and challenges can be extended ad libitum, but this is not the place to do it. Reduced to its barest essentials the problem of globalisation can be nicely expressed in the costs per production hour worked in a factory: for a western European country such as the Netherlands that figure is 25 Euro, near the border between Germany and Poland about 16 Euro, in Brazil 4, and in India and China not more than 1 Euro. That this forces the region to reform is widely recognised 
and accepted. Even so, most governments find it extremely difficult, if not downright impossible, to have an agenda for reform agreed to. Trade unions insist on maintaining acquired rights and opposing political forces make a clear choice for one approach or the other largely illusory. Anglo-Saxon neo-liberalism is welcomed by some, but seen as going against the grain of the best European social welfare traditions by others. In view of the need to maintain financial stability and to refrain from enlarging the national debt, certainly within the Euro zone, there is precious little scope to reallocate funds in support of costly pronatal policies. On the contrary; in search of saving opportunities employers may even seek to reduce childcare expenditure, while governments will find it difficult to maintain, let alone increase, the entitlements of working parents. 'Becoming a parent in Europe' is unlikely to become easier; that may have to await renewed economic growth a decade or so away.

\section{The outcome of pro-natal policies is in doubt}

Changes in fertility are customarily attributed to social change. That is to say, to a combination of changes in economic and social structure, in technology, or in the culture of a society. Frequently it is instructive to build the arguments for the motivation of the decline of fertility after the mid-1960s largely on only one or two of these, for example by arguing that improved contraception had a catalytic influence in a situation characterised by value change. Nevertheless, if the prospect of pro-natal policies is discussed it is necessary to recognise that pronatal policies may, at least in theory, use all three areas as their point of impact. Examples from the past are: prohibiting the production, advertising and sale of condoms, equating sterilisation with causing grievous bodily harm, disallowing abortion, introducing and increasing child benefits, marriage premiums, or pension provisions favourable to parents, decorating particularly prolific mothers, appealing to the people's love for the nation ("La France a besoin d'enfants"), and so on. Research into the effectiveness of pro-natal measures has yielded varied results and authors tend to complain about the methodological problems in assessing them (Ekert 1986; Höhn and Schubnell 1986; Klinger 1990; Gauthier 1996). It would appear, though, that in addition to influencing the timing of births a modest increase in ultimate family size may on occasion occur, while more recently a direct effect of policy changes on fertility behaviour has sometimes been established (Teitelbaum 1972; Hoem 1993; Hoem et al. 2001; Dalla Zuana and Marzia 2005). Even so, no one can with any degree of certainty specify which approach offers the best perspective and whether it is cost-effective. On the basis of the results of a Population Policy Acceptance Study (PPAS) recently carried out in Germany, Dorbritz (2004: 324) concludes that even if a whole series of currently advocated family policies were introduced this would not necessarily lead to an increase in the number of births. Most, more precisely $66 \%$, of the respondents would simply see it as making it easier for them to fulfill the extremely low wish for children [1.74 amongst women and 1.57 for men] they 
have. As sub-replacement family size ideals have earlier emerged in the Germanspeaking world (Goldstein et al. 2003), the drive in human populations to procreate may long have been over-estimated. Whether the German speakers will prove to be trendsetters in this regard or will remain the exception, as other PPAS results in Europe suggest, is a moot point. It may, obviously and for all sorts of reasons, be a good thing to introduce family policies enabling couples to combine work and parenthood. But can demographers really recommend them because of their assured, direct pro-natal effect? It would seem that for demographers and policy makers alike the well-known political adage, 'when in doubt, abstain' is a reasonable position to take. In any case, the analysis undertaken by Schultheis (1990) for France suggests that it really is only a broad pro-natal effort, not too concerned with cost-effectiveness and sustained for many decades, that is likely to have a lasting effect on the quantum of fertility. As such a large-scale and sustained national effort would, obviously, need to be legitimised by wide support in all social, ethnic, and political groupings in society. The French policy approach is not simply transferable to other national settings, for in that country successive armed conflicts with a large neighbour have instilled a particularly strong feeling about the importance of maintaining its numerical strength

\section{The past mainly yielded lamentable examples}

The shadows of the past make a dispassionate public discussion of the pros and cons of pro-natal policies an unattractive proposition. For politicians little is to be gained by broaching the subject. And indeed, if one lists the countries that at one time during their history made a serious effort to increase fertility the impression of a strong association with authoritarianism is unavoidable: Germany and Italy, during fascism; GDR, Czechoslovakia, Hungary, Romania and the like during communism. Are explicit pro-natal policies incompatible with the principles adhered to in democratic societies and is a plea for their introduction tantamount to inviting the government to become more authoritarian? That would certainly be overstating the case and the dangers: think of France, Singapore, and Sweden. At the same time one wonders whether these three examples do not confirm that a specific national strategy, great national pride, a broad national consensus, a strong central government, and a population willing to accept its authority in the matter, are pre-requisites for introducing explicit pro-natal policies? In each of these cases the reasons for the easy acceptance of pro-natal policies are readily understood given the country's history and position in the world. Even so, it is not inappropriate to recall that from the 1930s through the 1970s in Sweden, where the eugenics movement traditionally had great influence, around 62000 persons, $90 \%$ of whom were females, were coerced into accepting sterilisation, or were sterilised without their consent, because they were considered to be unfit to raise children. This was by no means an exception. A web search suggests that many more countries or states - such as Norway, Finland and the United States (North 
Carolina, for example) - followed practices now considered quite unacceptable and a violation of human rights.

\section{The process of social change will continue}

The process of social change never stops. As demographers are well aware it is the rapid succession of generations and cohorts that enables the indefinite continuation of that process. As the level of fertility is likely to change under the influence of social change this implies that one should not consider current levels to be immutable. In fact, it is precisely the essential characteristic of fertility under the impact of the Second Demographic Transition that should alert one to the probability of further change. For its most crucial element is that people determine the number of their children in full freedom and using all means of perfect birth control. Typically they will weigh a large number of factors before deciding to try and conceive a child or an additional child. In that sense fertility can best be described as a 'derivative'. When partners perceive that the benefitsespecially the way in which their life will be enriched-outweigh the (opportunity) costs they tend to commit themselves remarkably fully to a positive decision. Sophisticated women will then stop using the pill or another effective contraceptive, start taking folium acid tablets against spina bifida instead, and after a few months attempt to conceive. Conceptions are meant to be selffulfilling for the couple or individual. Of course, the process does not always unfold in this particular way and 'accidents happen'. But now that the mean age at birth has risen to 30 or so it is fair to assume that a great many of the potential parents will be experienced lovers and contraceptors. From the very low levels of fertility currently observed one may conclude that at the moment having children does not rate highly in the value system. In surveys respondents will give as their reason for not wanting a (further) child that they have not found the right partner, are concerned about the future which awaits children, or that in view of the high costs of children they prefer to maintain their standard of living. As Dalla Zuana (2004) recently observed for Italy, people '....are strongly oriented towards consumer goods connected with the quality of life in the home'. But values and perceptions may change. If at one time they were to conclude that actually raising a couple of children is preferable, more fashionable or prestigious, they would be entirely free to act on that preference.

If one follows what a number of leading politicians and political commentators drive at in their speeches, columns and books, it seems as if change is in the air. During a political debate on German TV an obviously well-respected professor stated brazenly: 'Die Gesellschaft ist marode, und die Familie ist marode', without being attacked fiercely. The Prime Minister of the Netherlands, Jan Peter Balkenende tried to make 'norms and values' the central theme of the half-year his country had the Presidency of the European Union in 2004. The British physician and publicist Theodore Dalrymple is, furthermore, quite outspoken in his condemnation of instant gratification, sexual freedom, extra- 
marital fertility, one-parent families and similar phenomena. Blaming the 1960s for all the things that have gone wrong in our societies has, more generally, become a favourite pastime. Whether the pendulum will swing back is difficult to tell, but there can be little doubt that neo-conservative forces are gaining in strength.

It is, further, essential to understand that the demographic regime change frequently described as a second transition is still underway. Postponement of births testifies to that and by itself is a clear manifestation of an ongoing process. The societies concerned have not only failed to devise ways that would make becoming a parent and combining that with a job more attractive. They have also failed to devise a strategy for dealing effectively with the integration of immigrants and the problem of international migration more generally. The efforts now forced upon them to make the labour market less rigid, to change employment conditions, 'to get the economy going again', and so forth, are bound to influence the regime change by affecting fertility decisions. Once our societies have gained a new sense of direction, more stable and sustainable demographic patterns may emerge.

\section{The international demographic setting requires restraint}

Another 3 billion men and women will, it would seem from probability projections published in Nature by Wolfgang Lutz and his colleagues (2003), be added to the world's population before natural growth has come to an end. In the foreseeable future the world will experience absolutely no shortage of people prepared to fill vacancies that might arise elsewhere. In all likelihood a steady stream of migrants will move towards the industrialised countries; in fact, they already are competing for talent! So, even if natural growth rates are negative, population loss will be the exception rather than the rule. In a purely demographic sense this phenomenon makes the situation in many countries less dramatic than a projection of natural growth suggests. Politicians and policy makers in quite a few, if not in all industrialised countries, have to take into account that part of the electorate may be strongly opposed to trying to raise the growth rate of the national population. These argue that the Western region would be better off with fewer people; that population decline is advantageous from an environmental point of view, and that international solidarity requires restraint on the part of the highly industrialised countries. They feel that Western countries should not advocate fertility decline in one part of the world and stimulate an increase in the number of births at home. In their view the population at large acts more sensibly than demographers advocating pro-natal policies. The argument that, in principle, there is nothing incongruent in a situation in which, in order to fulfill their main responsibilities, certain governments find they will have to stimulate fertility while others conclude that a lower level of fertility would be desirable, does not appeal to them. And neither are they impressed by the conclusion that migrants cannot be a substitute for births. In their view the joint effort of all nations is 
needed to put a halt to natural population growth and thus to safeguard the longterm future and bio-diversity of the earth. This approach to future population growth is not based on demographic considerations; it is primarily a reflection of the feeling that the world would be a better place to live in if there were fewer people. Perhaps it also is an expression of awareness of the so frequently highlighted risks involved in further growth and of anxiety about the future of the coming generations. In fact, fear for the future of their children is a frequently advanced argument of people not wanting to have them or not to have an additional child. Certain groups appear to ignore or challenge the received ideas quite deliberately. For example, in the Netherlands the so-called 'Club of Ten Million', which reportedly is supported by a rich industrialist, has as its main objective the reduction of the country's current population of 16 million or so to the 10 million mentioned in the name. This idea has now been floating around for decades; that it is not so easily accomplished does not seem to deter the club's adherents. ${ }^{2}$ In combination with emancipation movements that may feel their achievements threatened by policies perceived to be traditional and retrograde, these forces may amount to a formidable opposition. Politicians more interested in acquiring power than in attesting the farsightedness of their views may well feel deterred by that likely opposition and refrain from taking a strong stand regarding pro-natal policies.

\section{Fertility is largely beyond government control}

Restraint in interfering with fertility by means of explicit pro-natal policies is, finally, desirable because human reproduction may well be beyond a government's direct influence. As a matter of fact the decline of fertility as such may be assumed to be closely related to value changes in society that researchers have described as the shift from materialism to post-materialism, or also from modernism to post-modernism, to late-modernism, or reflexive modernism (Bertens 1995; Inglehart 1997). Whatever term one may prefer, this new stage in industrialised societies is characterised by a distrust of meta-narratives: of the great stories that underpinned societal progress and gave them a common purpose. The idea that the swarm may have priority over the bee is not at all common. To a considerable extent people have lost faith in the governments that represent them. They are wary of motives and promises. This has made the traditional administrative operating system obsolete. The time that governments and politicians could use an advantage in knowledge and power to broker a compromise between the desirable and practical and then enforce a specific

During deliberations about the draft Report of the Royal Commission on Population in the Netherlands in the early 1970s it was, for example, forcibly expressed by Nobel prize-winning economist Jan Tinbergen and his colleague Jan Pen, also an economist of repute. Very recently, when in a literary journal the latter reminisced about that exchange of views, he recalled that he had learned a great deal about demography when I reacted by saying that he would need a machine gun to achieve his stated goal of halving the population (Pen 2006). 
course of action has passed, as the political scientist Herman van Gunsteren argued in a address to the Social Science Council at the Royal Academy in Amsterdam. The gap between the population and its elected representatives is wide. Attempts to narrow and bridge it through referenda and hearings have been particularly unsuccessful. The 'no' vote in France and the Netherlands on the European constitutional treaty is a striking example. It occurred against the very outspoken wishes of the president/prime minister, the unwavering support of the leaders of the major political parties, and even the positive advice of the chairs of the trade unions. That the electorate is quick to vote in large numbers for flash-inthe-pan politicians similarly demonstrates a marked dissatisfaction with the present state of affairs. Van Gunsteren rightly argues that a better way forward is for governments to move from an operating system based on Analysis and Instruction to one based on Diversity and Selection. They will have to leave room for diversity and personal choice. The major challenge is to select which developments should be supported and which should be discouraged. Making decisions of this type presupposes having a clear set of values.

However, it is precisely in our post-modern, newly unordered societies, that reaching political agreement on such a set of values is terribly difficult. Major sections of the population differ in their views on the degree of freedom people should have. Some see run-away individualism and too much permissiveness as having disastrous consequences for the least educated and skilled sectors of the population. They would want to discourage cohabitation by refusing to pay social benefits to single parents and by stating clearly that births within marriage are to be preferred to extra-marital births. Against that, others plea for further emancipation and personal freedom: allow same-sex marriages, equalise the legal position of marriage and cohabitation, encourage, and pay for, in vitro fertilisation of single women, and the like. How does one under such circumstances reach agreement on which population policies would meet their essential objective of contributing to the wellbeing of the population and which would detract from it?

\section{Are Indirect Pro-natal Policies the Answer?}

In response to arguments such as sketched above, proponents of policy measures aimed at raising fertility advocate an indirect approach. In a sense they suggest introducing a new type of population policies: Policies taken with demographic intent but cognizant of their assumed beneficial effect for individual citizens and society as a whole. The list of options governments may have in this regard is long. What they amount to is promoting births through policies relating to the school system, working hours, employment, housing, tax transfers, intergenerational transfers, and the like. Such policies, it is argued, should support couples and individuals by enabling them a wider range of choice and, more specifically, in having the number of children they want and at the time they want 
(Frejka and Sardon 2005; Lutz and Skirbekk 2005). By not aiming at fertility directly but at the institutional and social environment in which couples make their decision, they hope to see fertility rise and/or couples decide for children earlier in their lives. However, cash payments at the time of birth of a child or targeted at certain demographic characteristics of the family may be included. In many respects the proposed measures are best characterised as family support policies and in discourse the distinction between explicit policies pro-natal policies and birth-promoting policies of this new type commonly is blurred. The basic assumption underlying this indirect approach is that according to their expressed views in surveys couples would like to have more children than they have. While they may wish to have two on average, they stop well short of that ideal. Why not create the institutional arrangements that would enable them to realise their wishes as it is also desirable from a societal perspective?

In an impressive series of papers Peter McDonald $(2000 ; 2002 ; 2005)$ has highlighted the principles upon which 'family support policies should be based'. Almost unavoidably such principles have a clear ideological component; more specifically, this view on society expounds values such as gender neutrality and generational equity; full workforce participation as seen as a normal state of affairs. Nevertheless, in many respects this indirect approach to stimulating fertility seems more promising than the direct approach. One may well argue that it will help completing the regime change underway since the mid-1960s and is necessary in enabling people to combine the role of active participant on the labour market with that of parent. Sweden, and more generally the Scandinavian countries, is then presented as a country where the new realities of family life have been handled so successfully that fertility can be maintained close to replacement level.

However, from a government's point of view the indirect approach also has some serious drawbacks. Aside from the fact that the outcome of indirect measures is more difficult to assess than that of direct measures and may also be less effective, its main weakness is uncertainty about the validity of the underlying assumption. Is it really reasonable to assume that removing obstacles to combining the parental and labour force roles will result in higher fertility? Does not the experience from the past show that women will use better circumstances and enlarged options primarily to increase their labour force participation? And, is it really likely that couples will use improvements in their living conditions to have (more) children rather than to spend funds on other priorities? Can one really maintain that the competition of other priorities such as holidaying, improving the house and its installations, or following one's soccer club to the corners of Europe, will be much reduced as a result of the sort of measures proposed? No doubt, young couples will welcome the prospect of receiving approval of society for being prepared to fulfill the role of parent and of collecting some compensation for costs incurred. But will it allay the fears for the future of their children? And will they, as Dorbritz (2004) reported, see it as more 
than something making their life somewhat easier? Would it really bring them to having a baby or another baby? And, will couples and individuals that have decided to remain voluntary childless change their mind in view of beckoning rewards? The list of rhetorical questions can easily be extended. But that is not the point. Posing them suffices to illustrate that demographers would have difficulty in answering such straightforward questions unambiguously. The central issue is, of course, whether people have so few children by default or by design.

Another drawback is the costs of the proposed measures. Some steps, as McDonald has rightly stressed, can be taken in a budgetary neutral way. Politicians can, for example, decide that children should in principle have access to their school from 7 o'clock in the morning to $6: 30$ in the evening. Who should look after them there: unpaid volunteers? There can be no doubt that a revision of institutional and social arrangements in society to promote childbirth will be a costly affair. And since, as discussed earlier, economic restructuring and reforms need to have priority over policies pro-natal in content, it is doubtful that the monies required will be forthcoming. The so-called Scandinavian model presupposes that governments pay from the public purse what in other countries people would have to pay for themselves. Obviously they can only do that by first collecting the necessary funds. As Scharpf (2000) has highlighted this is problematic. As regards corporate taxes governments find themselves engaged in what has been characterised as a 'race to the bottom'. To attract firms, and out of fear that others will simply move part of their activity to another countryreportedly Microsoft has a branch in Ireland to receive the revenues from the international sale of software to save on taxes - they are intent on continually offering them the best possible tax conditions. Provisional OECD statistics for 2004 show that with $50.7 \%$ Sweden had the highest tax revenue as a percentage of GDP in all OECD nations, with Denmark (49.6), Norway (44.9) and Finland (44.3) all being amongst the top 5. As tax relief for families is not included in this figure but cash transfers are this does not tell the whole story. Even so, whether other countries will move towards the 'Scandinavian model' instead of in the direction of greater liberalisation is a moot point. The more so since Birgitta Swedenborg, a well-known Swedish economist has, just as in the mid-1990s, recently exposed several weaknesses in the Swedish model. It is by no means free of problems, sharing with other countries the unsuccessful integration of migrants and minimal wages that are too high in the global setting. Hidden unemployment is marked, and if unemployment benefits and the costs of health insurance rise, family benefits are likely to come under pressure.

Opting for or against the so-called 'Scandinavian model' is a political decision. But, political parties in most European societies are sharply divided on the issue of how best to face the future: neo-liberalism or renewed socialism? Even if a 'Third Way' is being tried strong majorities are rare. The proportion of parliamentary votes frequently remains roughly in equilibrium so that, unless the outcome of an election leaves no other choice than to form a grand coalition, the 
process of structural and institutional reform that could encompass and revise family policies will presumably make very slow progress only.

One may conclude from all this that from a government's or politician's perspective many of the practical obstacles in the way of explicit pro-natal policies apply equally to the indirect approach of promoting births.

\section{Which Way Forward?}

The list of arguments discussed above poses the question whether there is any way forward? How does one deal with a fertility decline to such a low level that the size of future generations of men and women will be not much more than half of those now economically active. If governments on very good grounds are concerned about lowest-low fertility and feel they would be remiss in their duty if no action were taken, what could they do? What would be the best way forward?

The first task, presumably, would be to raise awareness. Demographers, economists and other scholars have an important role to play in this regard in that they should provide the impartial information on which both governments and citizens can rely. They should point to research findings as those of Neels (2005) who recently established for Belgium that the economic factors play a more important role in influencing the frequency of births with low rank numbers while ideational factors have the greatest influence concerning the higher rank numbers and the shifts in marriage patterns. They should, similarly, point to research findings obtained through analysis of policy acceptance surveys in countries characterised by 'weak' as well as 'strong' families (Micheli and Dalla Zuana 2004). They should also refer to studies about increasing voluntary childlessness, for example the recent findings presented by Dorbritz (op. cit., 324) who noted that pro-natal measures such as a single financial bonus for the birth of a child were of little interest to his respondents. They should, in addition, explore ways of alleviating the impact of low fertility by simulating varying levels of immigration and emigration, changes in labour force participation, levels of part-time employment, and the like. Governments intent on halting or reversing the trend in fertility will, secondly, have to investigate which possible actions:

i. Would be valuable in themselves and might contribute to the desired effect,

ii. Would not be discriminatory as regards social class, race, religion and such other factors as are enshrined in a country's Constitution,

iii. Would respect the internationally agreed upon right of individuals and couples to decide freely and responsibly on the number and spacing of their children,

iv. Would appeal to broad sections of the population and not solely to those few age groups likely to benefit temporarily from them,

v. Would be seen to be of direct and long-term benefit to society and the formation of the coming generations, 
vi. Would, in all likelihood, aid the completion of the demographic regime change currently underway and would be sustainable in the foreseeable future,

vii. Would, consequently, probably receive broad political support.

This identifies investing in the coming generations as possibly the best way forward. According to some futurologists, industrialised nations will have to meet international competition by raising the future elite as best they can. Every opportunity to develop themselves should be offered to young men and women who have the talents to invent new techniques, and to see new opportunities from which society as a whole may benefit. Not numbers of children will be the decisive factor for the common future but the quality and level of education of those that are born. Parents like to see their children do well. In fact, a great deal of hope and expectation is commonly vested in them. This especially in a situation where conceptions have to be self-fulfilling, where after much deliberation the advantages of having a (further) child are perceived as outweighing the disadvantages, and conceiving mostly requires the conscious decision to interrupt contraception. Policies concentrating on the formation, education and training of children until they reach adulthood would seem to meet the list of criteria. Raising children with a hunger for knowledge, a sense of adventure and endeavour, confidently looking forward to face international competition, and intent on making the most of opportunities offered, might be a better policy option than trying to increase their numbers. No doubt, such measures are expensive. But investments in education, training, and research commonly yield good returns. This might help reaching political agreements. Our societies are bound to benefit immensely from young generations with a confidence and attitude commensurate with that of the young in China, India, other parts of Asia and, more generally, in the developing world. And, at the very least, it would brighten the prospects of these coming generations themselves while conveying to potential parents that society at large would be appreciative of their individual efforts to contribute to raise a strong, new generation.

\section{References}

Berelson, B. 1971. "Population policy: personal notes." Population Studies 25(2): 173182.

Berelson, B. 1974. 'Introduction'. In: B. Berelson (ed.) Population Policy in Developed Countries. New York: MacGraw-Hill Book Co.

Bertens, H. 1995. The Idea of the Postmodern: A History. London: Routledge.

Brouwer, H. J. 2005. “Germany's economic future. A response to Horst Siebert's Jelle Zijlstra lecture." NIAS Newsletter 34: 20-23.

Cline, R. S. 1975. World Power Assessment: a Calculus of Strategic Drift. Washington DC: Center for Strategic and International Studies, Georgetown University. 
Dalla Zuana, G. 2004. "The banquet of Aeolus. A familistic interpretation of Italy's lowest-low fertility." In: G. Micheli and G. Dalla Zuanna (eds.) Strong Family and Low Fertility: A Paradox? Dordrecht, European Association for Population Studies: Kluwer Academic Publishers, pp. 105-125.

Dalla Zuana, G. and L. Marzia. 2005. Assessing the Impact of National and Regional Financial Incentives for Childbearing in a Lowest-Low Fertility Setting. Paper presented at the IUSSP General Conference, Tours, June 2005.

Davis, K. 1954. "The demographic foundations of national power.” In: M. Berger et. al. (eds.) Freedom and Control in Modern Society, New York.

Davis, K. 1958. "Population and power in the free world." In: P. M. Hauser (ed.) Population and World Politics, Glencoe (Illinois): Free Press.

Demeny, P. 2003. "Population policy dilemmas in Europe at the dawn of the twenty-first century." Population and Development Review 29(1): 1-28.

Don, H. 2006. Interview published in NCR Handelsblad. 9 February 2006.

Dorbritz, J. 2004. "Demographische Trends und Hauptergebnisse der deutschen Population Policy Acceptance Study (PPAS)." Zeitschrift für Bevölkerungswissenschaft 29(3-4): 315-328.

Doublet, J. 1949. "Des lois dans leur rapport avec la population." Population 4(1): 39-56.

Ekert, O. 1986. "Effets et limites des aides financières aux familles: Une experience et un modèle." Population 41(2): 327-348.

Frejka, T. and J.-P. Sardon. 2005. Contemporary Fertility Trends in the Developed Countries: Further Decline, Plateau or Upswing. Paper presented to the IUSSP General Conference, Tours, June 2005.

Gauthier, A. 1996. The State of the Family: A Comparative Analysis of Family Policies in Industrialized Countries. Oxford: Clarendon Press.

Goldstein, J., W. Lutz, and M. R. Testa. 2003. "The emergence of sub-replacement family size ideals in Europe." Population Research and Policy Review 22(5-6): 479-496.

Hartog, J. 2005. Bevolkingsomvang moet omlaag (Population size should be reduced). Opinion published in NRC Handelsblad.

Hoem, J., A. Prskawetz, and N. Neger. 2001. "Autonomy or conservative adjustment? : the effect of public policies and educational attachment on third births in Austria 1975-96." Population Studies 55(3): 249-262.

Höhn, Ch. and H. Schubnell, H. 1986. "Bevölkerungspolitische Massnahmen und ihre Wirksamkeit in ausgewählten europäischen Industrieländern." Zeitschrift für Bevölkerungswissenschaft 12(1 and 2): 3-51 and 185-219.

Inglehart, R. 1997. Modernization and Postmodernization: Cultural, Economic, and Political Change in 43 Societies. Princeton: Princeton University Press.

Klinger, A. 1990. "Demographische und andere Techniken zur Messung der Wirkung politischen Handelns auf Bevölkerungsvorgänge.” In: H. Birg and R. Mackensen (eds.) Demographische Wirkungen politischen Handelns. Institut für Bevölkerungsforschung und Sozialpolitik, Bielefeld: Campus Verlag, pp. 83-103.

Lutz, W., W. Sanderson, and S. Scherbov. 2001. "The end of world population growth." Nature 412: 543-545.

Lutz, W. and V. Skirbekk. 2005. "Policies addressing the tempo effect in low-fertility countries." Population and Development Review 31(4): 699-720.

McDonald, P. 2000. "Gender equity, social institutions and the future of fertility." Population and Development Review 26(3): 427-439. 
McDonald, P. 2002. "Sustaining fertility through public policy: the range of options." Population 57(3): 417-446.

McDonald, P. 2005. Fertility and the State; the efficacy of policy. Paper presented to the IUSSP General Conference, Tours, June 2005.

Micheli, G. and G. Dalla Zuanna (eds.) 2004. Strong Family and Low Fertility: A Paradox? European Studies of Population, Vol. 14, Dordrecht, European Association for Population Studies: Kluwer Academic Publishers.

Mills, M. and H.-P. Blossfeld. 2005. "Globalization, uncertainty and the early life course. A theoretical framework." In: H.-P. Blossfeld, E. Klijzing, M. Mills, and K. Kurz (eds.) Globalization, Uncertainty and Youth in Society. London: Routledge, pp. 1-25.

Neels, K. 2005. Uitstel van Vruchtbaarheid: Nieuwe Waarden of Structurele Verandering. MS, Brussels.

Organski, K. and A. F. K. Organski. 1961. Population and World Power, New York.

Pen, J. 2006. "Met Jan Tinbergen - II." Hollands Maandblad 1: 18-25.

Scharpf, F. W. 2000. "The viability of advanced welfare states in the international economy. Vulnerabilities and options." European Review 8(3): 399-426.

Schultheis, F. 1990. "Die pronatalistische Bevölkerungspolitik in Frankreich.” In: H. Birg and R. Mackensen (eds.) Demographische Wirkungen politischen Handelns. Institut für Bevölkerungsforschung und Sozialpolitik, Bielefeld: Campus Verlag, pp. 303355.

Siebert, H. 2005. Germany's Stalling Economic Engine - How to Get it Running Again. Jelle Zijlstra Lecture 3, NIAS, Wassenaar.

Teitelbaum, M. 1972. "Fertility effects of the abolition of legal abortion in Romania." Population Studies 26(3): 405-417.

Van de Kaa, D. J. 1978. "Towards a population policy for western Europe." In: Population Decline in Europe, Council of Europe; London: Edward Arnold, pp. 215230. 